illustrating the aids and appliances which can be helpful. Because there are few children with osteogenesis imperfecta in any area, doctors, therapists, and social workers are seldom familiar with their needs. The demonstrations on television helped many parents to know what was possible.

This is just one of the ways in which television can be of real help to us in medicine. To exploit the medium we need more insight into its workings. I suspect that many of the difficulties described by your correspondent arose because we fail to speak in a language the public understands or because we do not appreciate that the producers, reporters, and researchers are professionals in their own right. The words of Cromwell that we should "think it possible that we are mistaken" apply with as much force to ourselves.

\section{R Paterson}

University Department of

Biochemical Medicine,
Ninewells Hospital and Medical

Ninewells
School

Dundee

\section{Fatal chlormethiazole poisoning in} chronic alcoholics

SIR,-I would like to draw your attention to two basic errors in the article by Dr Joan M Horder (3 September 1977, p 614), one of which significantly affects the conclusions drawn while the other must give rise to considerable confusion.

Dr Horder, in referring to the findings of Fischler et al, , $^{1}$ states that "the ingestion of two 500-mg tablets of chlormethiazole edisylate produces a maximum concentration of about . . $1.0 \mathrm{mg} / 100 \mathrm{ml}$ plasma after 70 minutes." It would appear that Dr Horder misread the original data, which indicated that this dosage produced a maximum level of about $1 \mu \mathrm{g} / \mathrm{ml}$ $(0 \cdot 1 \mathrm{mg} / 100 \mathrm{ml})$, a tenfold difference. We have checked with one of the authors (Örtengren), who has confirmed that the mean maximum concentration at the time stated was $0.122 \mathrm{mg}$ chlormethiazole base $/ 100 \mathrm{ml}$. There is thus a much wider margin between the therapeutic plasma concentration of chlormethiazole and the lowest recorded fatal level $(2.5 \mathrm{mg} / 100 \mathrm{ml})$ than appeared from Dr Horder's paper, and her statement that her findings "question the statement that the drug is of low toxicity" is hardly justified.

The second error concerns the substance (molar) concentrations of the drug given throughout Dr Horder's paper. It must be assumed that the concentrations measured by Dr Horder were, like those of Fischler et al, those of chlormethiazole base and that they were originally expressed in mass units, as is customary, so that the values given in parentheses in the paper are the original ones obtained. The substance concentrations ( $\mu \mathrm{mol}$ / 1) given, however, appear to have been calculated from the mass concentrations by means of a factor derived from the molecular weight of chlormethiazole edisylate (513.5), which differs very considerably from that of chlormethiazole base (161.65). This miscalculation has thus given values which are approximately one-third of the true substance concentrations of chlormethiazole base, an anomaly which makes them incomprehensible and confusing.

The reliability of drug concentration findings in samples of blood taken post mortem is doubtful. ${ }^{2}$ This is perhaps also a point where Dr Horder's findings might be questioned in the light of the number of tablets reported to be recovered post mortem.

Concerning the criticism of Dr Horder's article with regard to certain misleading statements made about medical indications for chlormethiazole in alcoholics, we fully endorse the views expressed by Dr J J Bradley (17 September, p 774) and Dr M M Glatt (22 October, p 1088). We do not consider chlormethiazole to possess specific antidepressant properties. It is a sedative/hypnotic and anticonvulsant. ${ }^{3}$ It has also been shown to have anxiolytic properties. ${ }^{4}$ Its use in alcoholism should be reserved for the management of acute withdrawal symptoms, including delirium tremens, preferably in a hospital-type setting where there are adequate facilities for supervision. The length of treatment should be limited to about eight days. Under such treatment conditions Glatt, ${ }^{56}$ as reaffirmed in his recent letter (22 October, $p$ 1088), found there was no justification to contraindicate the use of chlormethiazole in the presence of depression. However, long-term outpatient treatment with sedative/hypnotics of an alcoholic patient suffering from depression may constitute a risk.

Finally, I would like to thank Dr Horder for reporting her cases. Through her article the medical profession has been rightly warned of the risk involved in combining alcohol with sedative/hypnotics in outpatients suffering from alcoholism and depression. These at-risk patients should not be prescribed large quantities of any sedative/hypnotic.,

$$
\begin{array}{r}
\text { IAN M SLESSOR } \\
\text { Medical Adviser, } \\
\text { On behalf of Astra Chemicals Ltd, } \\
\text { Watford, England, and } \\
\text { Astra Läkemedel AB, Sweden }
\end{array}
$$

Watford, Herts

' Fischler, S, Frisch, P, and Örtengren, B, Acta Pharmacologica Suecica, 1973, 10, 483. Gee, D J, Ciba Foundation Symposium 27 (new series), p 239. Amsterdam, Excerpta Medica, 1974. Lechat, P, Acta Psychiatrica Scandinavica, 1966, 42, suppl 192, p 15.

Haslam, M T, Pharmatherapeutica, 1976, 1, 2

Glatt, M M, and George, H R, British Medical fournal, 1964, 2, 445. Medical fournal, $1965,2,201$.
latt, $M$, George, $\mathrm{H}$, and P, British

${ }^{*}{ }^{*} \mathrm{Dr}$ Slessor is quite correct in his diagnosis of the mistake that was made, in this office, in converting Dr Horder's original mass concentrations of chlormethiazole base (in $\mathrm{mg} / 100 \mathrm{ml}$ ) into substance concentrations of the edisylate (in $\mu \mathrm{mol} / \mathrm{l}$ ). This was a subeditorial error for which we apologise and accept full responsibility (see leading article, p 668). Dr Horder's own reply to Dr Slessor's letter is printed below, while a revised version of her original short report appears at p 693ED, $B M F$.

SIR,-In replying to Dr Slessor's letter I shall deal with the points in the order in which they are raised, with the exception of the error in conversion of the chlormethiazole concentrations into SI units, to which you have already replied.

Dr Slessor is quite correct when he states that the figures quoted from the paper of Fischler et al were misread. A poor-quality photostat was mainly responsible. I sincerely regret the error and apologise to Astra Chemicals for any embarrassment caused to them. There is indeed a wider margin between the therapeutic plasma concentration of chlormethiazole when taken in tablet form and the lowest recorded fatal levels $(2.5 \mathrm{mg} / 100 \mathrm{ml}$ of chlormethiazole alone and $0.5 \mathrm{mg} / 100 \mathrm{ml}$ of chlormethiazole when taken with alcohol. $)^{1}$

The amount of a drug found in the stomach merely indicates the minimum quantity ingested and bears no relation to levels of drug attained in the plasma. Those intent on suicide invariably take far more of a noxious substance than is required to kill.

I did not state that chlormethiazole was an antidepressant (19 November, $p$ 1354). Since, however, clarity seems to have suffered in the condensation of the report I have rephrased the offending sentences in the revised version.

I do not agree with Dr Slessor that "long term outpatient treatment with sedative/ hypnotics of an alcoholic patient suffering from depression may constitute a risk" (my italics). It clearly does, as five fatal cases in one district over a $2 \frac{1}{2}$-year period shows. I note that since October 1977 local pharmacists and the hospital pharmacy have received supplies of chlormethiazole in bottles which now bear a warning label to the effect that it is additive with alcohol.

I hope that the revised version of the article with the drug concentrations expressed in the form as originally submitted to the $B M F$, together with this letter, will correct the errors and misunderstandings which have occurred.

\section{J M HORDER}

Department of Pathology,

Bedford General Hospital (South Wing), Bedford

Jakobsson, S, and Möller, M, in Abstracts of the Sixth International Meeting of Forensic Sciences, the British Pharmaceutical Industry.

\section{College of Anaesthetists}

SIR,-I write in response to the letter from Professor Donald Campbell and others (4 March, p 574) on the subject of a College of Anaesthetists. They suggest that the new charter of the Royal College of Surgeons of England offers complete independence to anaesthetists within the college. The new charter certainly does not offer parity-the number of fellows of the Faculty of Anaesthetists on the college council is not equal to the number of surgical fellows. Indeed, it would be unreasonable to expect our surgical colleagues to agree to this intrusion in their own college. They have conceded as much as they can and we are grateful to them for so much help in our adolescent years as a specialty.

However, anaesthesia has now fully matured as a specialty, and, as the letter from the President of the Royal College of Surgeons and the deans of its faculties recently sent to all fellows points out, it is not unreasonable for many anaesthetists to aspire to complete independence in the form of their own college. The matter has already been under debate within the specialty for some 10 years, and the majority of those who have been unconvinced about the wisdom of establishing a college are concerned on financial grounds. The matter of finance is now being put to the test and the success or otherwise of the fund-raising activities will surely provide for a sensible and proper decision to be made as to whether a college should be founded or not. It is to be hoped that, when the decision is made, the verdict will be graciously accepted and supported by all anaesthetists whatever their current views. 